\title{
Environmental and Management Factors Associated with Bacterial Diseases of Onion in Pennsylvania
}

Emily E. Pfeufer and Beth K. Gugino, ${ }^{\dagger}$ Department of Plant Pathology and Environmental Microbiology, The Pennsylvania State University, University Park, PA 16802

\begin{abstract}
Bacterial diseases of onion may result in over $60 \%$ yield loss in crops grown in the Mid-Atlantic region, even when managed with recommended chemical and cultural practices. To identify environmental and production factors associated with the high incidence of bacterial rots in Pennsylvania, data on 32 environmental and management variables ranging from soil temperature to foliar nutrients were recorded during three visits to each of 28 and 26 fields, surveyed in 2011 and 2012, respectively. Multiple linear regression indicated negative relationships

between foliar nitrogen and carbon at midseason and total incidence of bacterial rots. Soil temperatures near the physiological onset of bulbing were positively related to bacterial rots in multiple datasets. These results suggest greater complexity may be necessary for $\mathrm{N}$ fertility recommendations: timing of inorganic $\mathrm{N}$ application should be considered in addition to the seasonal $\mathrm{N}$ rate applied. Lower soil temperatures, particularly near the physiological onset of bulbing, may also reduce the incidence of bacterial rots of onion.
\end{abstract}

Bacterial diseases significantly reduce marketable yields in commercial onion production in Pennsylvania with losses approaching $60 \%$ in some fields in recent years. However, losses can be highly variable among seasons, farms, and fields (J. Stoltzfus, personal communication). In Pennsylvania, leaf blight and bulb rot, commonly referred to as center rot, caused by Pantoea agglomerans Beijerinck, and soft rots, caused by Pectobacterium carotovorum subsp. carotovorum Jones and Pseudomonas marginalis pv. marginalis Stevens, are the most common diseases observed in the field (E. Pfeufer and B. Gugino, unpublished). P. agglomerans inducing leaf blight, bulb rot, and center rot has been reported in Georgia (Edens et al. 2006) and caused substantial losses in Michigan in 2013 (Tho et al. 2015). Pseudomonas spp. and Pectobacterium spp. have long been associated with onion decay in New York (Kawamoto and Lorbeer 1967), New Zealand (Wright 1993), and in many other onion-growing regions (Mohan 2008).

Applications of copper tank-mixed with ethylene-bis-dithiocarbamate (EBDC) fungicides are primarily relied upon for bacterial disease management (Gent and Schwartz 2008; Sanchez et al. 2014); however, these may not be consistently effective on bacterial diseases of onion (Gent and Schwartz 2005). In addition, copperresistant strains of Pantoea ananatis from Georgia (Nischwitz et al. 2007) have been identified, which suggests the potential for resistant strains to develop in other production regions where frequent applications of copper are relied upon. Aside from copper-EBDC programs, growers have infrequently integrated biological or plant defense inducing compounds into their spray programs for onion

${ }^{\dagger}$ Corresponding author: B. K. Gugino; E-mail: bkgugino@psu.edu

Funding: This work was supported by the USDA National Institute of Food and Agriculture, Northeast Regional Integrated Pest Management Competitive Grant 2011-00535, Hatch Multistate Research Project W2008, SmithLever Appropriations as well as The Pennsylvania State University College of Agricultural Sciences, Pennsylvania Vegetable Growers Association and Pennsylvania Vegetable Marketing and Research Program.

Current address of E. E. Pfeufer: 201F Plant Science Building, Department of Plant Pathology, University of Kentucky, Lexington, KY 40546.

*The $\boldsymbol{e}$-Xtra logo stands for "electronic extra" and indicates that three supplementary tables are published online.

Accepted for publication 15 May 2018.

(c) 2018 The American Phytopathological Society disease management, although these have not been adopted on a broad scale.

Recommended cultural strategies for management of bacterial diseases include crop rotation, optimizing soil fertility (Diaz-Perez et al. 2003; Mohan 2008), using different types of plastic mulch (Gitaitis et al. 2004; Gugino et al. 2011), management of thrips vectors (Dutta et al. 2014), and intensive weed management in and around onion fields (Gitaitis et al. 2003). In the Vidalia onion cropping system, the common weed Florida pusley was found to maintain large epiphytic populations of the onion pathogen $P$. ananatis (Dutta et al. 2017). High amounts of rainfall and high relative humidity are associated with onion bacterial disease development in Colorado (Schwartz et al. 2003). Low-lying areas within onion fields have been noted to have higher incidences of bacterial disease (E. Pfeufer and B. Gugino, unpublished), but whether this is due to excess soil water or fertilizer accumulation is unknown. Bacterial pathogens of onion have varying optimal temperatures for growth; however, warmer air temperatures have been correlated with higher incidence of center rot (caused by $P$. ananatis) in Colorado (Schwartz et al. 2003). Both western flower thrips, Frankliniella fusca, and onion thrips, Thrips tabaci, have been demonstrated to vector bacterial pathogens of onions (Dutta et al. 2014, 2016). Similar to bacterial diseases in other pathosystems, an integrated management approach is needed to address potential sources of inoculum as well as bacterial disease progression (Obradovic et al. 2008).

To facilitate the targeted development and refinement of disease management strategies for bacterial diseases in the Mid-Atlantic region, hypothesis-driven, replicated survey plots were established on commercial farms across Pennsylvania in 2011 and 2012 to identify management and environmental factors associated with bacterial diseases leading to bulb rots of onion. Based on previous observations and published literature, it was hypothesized that soil nitrogen and soil temperatures would be positively associated with the incidence of bacterial rots of onion in these systems.

\section{Materials and Methods}

Field selection. In 2011 and 2012, 28 and 26 onion fields, respectively, were visited three times during each growing season. All 54 fields were planted with bare-root 'Candy' onion transplants sourced from either Dixondale Farms, Carrizo Springs, Texas or Sunbelt Transplant Inc., Buckeye, Arizona. In Pennsylvania (PA), onions are transplanted in late March or early April into fields ranging between 0.25 and 1.5 hectares; most fields are rotated annually among multiple crop families. PA onions are typically produced on embossed black plastic mulch-covered raised beds with two rows of drip irrigation, intensive fertigation programs, regular 
crop rotation, hand-weeding, and the use of copper tank-mixed with EBDC fungicides for bacterial disease management (Conover and Gerhold 1981). The use of other chemical management, including pre- and postemergent herbicides and insecticides for reducing onion thrips (Thrips tabaci Lindeman) populations, are variable among PA growers. Throughout July, onions are handpulled and dried in the field for several days before being handtopped, placed in bins, and fan-cured under rain shelter for at least 14 days.

The majority of sampled fields, 51 of 54 , were hand-transplanted with $15 \mathrm{~cm}$ between each plant within and between rows, with four rows across the bed. One field was mechanically transplanted along with two other hand-transplanted fields, where transplants were spaced approximately $20 \mathrm{~cm}$ between plants.

Field visits and data collection. Plot establishment. In April/May of each sampling year, characteristics of each production field were recorded, including type of plastic mulch, plant spacing, and approximate field size. Three $9.1 \mathrm{~m}$ plots were established in an area of the field visually determined to be representative of the entire field with respect to field length, width, and topography. Each plot was one bed wide, with typical bed width of $1.4 \mathrm{~m}$, and located in a unique row.

Soil-associated variables. Soil texture estimates were determined by selecting the cropped field as a region of interest in the NRCS Web Soil Survey (https://websoilsurvey.sc.egov.usda.gov/App/ WebSoilSurvey.aspx), choosing physical properties under Soil Data Explorer, and surface layer as the depth under the percent clay (silt, sand) navigation tab.

For the duration of the season, temperature sensors (HOBO Pendant Temperature Data Logger; Onset, Pocasset, MA) were placed in two of the three plots at a $7.6 \mathrm{~cm}$ soil depth beneath the plastic mulch. Hourly average soil temperatures for the duration of the season were downloaded using Base-U-1 and HOBOware (Onset Computer Corp., Bourne, MA). Temperature data were aligned by harvest date, and average soil temperatures by week preharvest were calculated for each field. In $96 \%$ of the fields, the data consisted of the average of the two soil temperature sensors; for two fields, these data were based on a single sensor due to malfunction and/or sensor loss. Additionally, cumulative total hours of temperatures at or above $30^{\circ} \mathrm{C}$ (optimal temperature for growth of members of the family Enterobacteriaceae, including Pantoea spp. and Pectobacterium spp.; Imhoff 2005) were calculated for each farm.

Composite soil samples were collected at plot establishment and at harvest, and consisted of six equidistantly spaced subsamples, which were collected from each plot using a soil probe $2.54 \mathrm{~cm}$ in diameter to a depth of $7.6 \mathrm{~cm}$ and bulked. Soil subsamples were homogenized by hand in plastic zip-bags, and approximately $15 \mathrm{~g}$ was placed in a screw-top cup containing $100 \mathrm{ml} 2 \mathrm{M} \mathrm{KCl}$ and shaken well for soil nitrogen testing (described below). To measure potentially mineralizable nitrogen (PMN), another $15 \mathrm{~g}$ was placed in a dry, empty screwtop soil cup, and all six cups per field were placed on ice in an insulated cooler for transport to the lab.

Upon arrival at the lab, samples in $\mathrm{KCl}$ were placed in a $4^{\circ} \mathrm{C}$ refrigerator, and dry cups were placed in a lab drawer at ambient temperature, with the lids loosened, for 31 to 40 days for soil nitrogen determination. Samples in $2 \mathrm{M} \mathrm{KCl}$ were extracted within 5 days of removal from field, and dry soil cups were extracted after incubation by agitating for $1 \mathrm{~h}$ after adding $100 \mathrm{ml} 2 \mathrm{M} \mathrm{KCl}$. Each $\mathrm{KCl}$ extract was filtered through premoistened Whatman No. 1 filter paper; then

Table 1. Environmental and management variables recorded on one or more of three sampling dates in PA onion fields in 2011 and 2012

\begin{tabular}{|c|c|c|}
\hline Variable & Sampling date & Type of variable ${ }^{a}$, units \\
\hline Early season soil $\mathrm{NO}_{3}$ & 1 & mg / kg dry soil \\
\hline Early season soil $\mathrm{NH}_{4}$ & 1 & mg / kg dry soil \\
\hline Gravimetric water content of soil (GWC) & 1 & $\%$ \\
\hline Potentially mineralizable N (PMN) & 1 & mg / kg dry soil day \\
\hline Soil sand content & NRCS survey & Midpoint of range, $\%$ \\
\hline Soil silt content & NRCS survey & Midpoint of range, $\%$ \\
\hline Soil clay content & NRCS survey & Midpoint of range, $\%$ \\
\hline Foliar tissue $\mathrm{N}$ & 2 & mg N / kg dry tissue \\
\hline Foliar tissue $\mathrm{C}$ & 2 & $\mathrm{mg} \mathrm{C} / \mathrm{kg}$ dry tissue \\
\hline Average bulb size & 2 & Ordinal, $1-3$ \\
\hline Purple blotch pressure & 2 & Ordinal, 0 - 2 \\
\hline Sunscald & 2 & Binary \\
\hline Proximity of mulch to bulbs & 2 & Ordinal, $1-3$ \\
\hline Mulch integrity & 2 & Ordinal, $1-3$ \\
\hline Weed pressure in raised beds & 2 & Ordinal, $1-3$ \\
\hline Weed pressure between raised beds & 2 & Ordinal, 1 - 3 \\
\hline Foliar thrips damage & 2 & $\%$ of leaf affected \\
\hline Harvest disease incidence & 3 & $\%$ Symptomatic bulbs \\
\hline Harvest soil $\mathrm{NO}_{3}$ & 3 & mg / kg dry soil \\
\hline Harvest soil $\mathrm{NH}_{4}$ & 3 & mg / kg dry soil \\
\hline Gravimetric water content of soil (GWC) & 3 & $\%$ \\
\hline Bulb tissue $\mathrm{N}$ & 3 & mg N / kg dry tissue \\
\hline Bulb tissue $\mathrm{C}$ & 3 & $\mathrm{mg} \mathrm{C} / \mathrm{kg}$ dry tissue \\
\hline Hours with soil temperatures $>30^{\circ} \mathrm{C}$ & Season-long & Count \\
\hline Average soil T 7 weeks preharvest ${ }^{\mathrm{b}}$ & 7 wk preharvest & ${ }^{\circ} \mathrm{C}$ \\
\hline Average soil T 6 weeks preharvest ${ }^{\mathrm{b}}$ & 6 wk preharvest & ${ }^{\circ} \mathrm{C}$ \\
\hline Average soil T 5 weeks preharvest ${ }^{\mathrm{b}}$ & 5 wk preharvest & ${ }^{\circ} \mathrm{C}$ \\
\hline Average soil T 4 weeks preharvest ${ }^{\mathrm{b}}$ & 4 wk preharvest & ${ }^{\circ} \mathrm{C}$ \\
\hline Average soil T 3 weeks preharvest ${ }^{\mathrm{b}}$ & 3 wk preharvest & ${ }^{\circ} \mathrm{C}$ \\
\hline Average soil $\mathrm{T} 2$ weeks preharvest ${ }^{\mathrm{b}}$ & 2 wk preharvest & ${ }^{\circ} \mathrm{C}$ \\
\hline Average soil $\mathrm{T} 1$ weeks preharvest $\mathrm{t}^{\mathrm{b}}$ & $1 \mathrm{wk}$ preharvest & ${ }^{\circ} \mathrm{C}$ \\
\hline Storage disease incidence & Storage & $\%$ Symptomatic bulbs \\
\hline Bulb tissue $\mathrm{N}$ & Storage & mg N / kg dry tissue \\
\hline Bulb tissue $\mathrm{C}$ & Storage & mg C / kg dry tissue \\
\hline
\end{tabular}

a Unless specifically noted, variables were continuous.

${ }^{b}$ Daily average soil temperature data were normalized by harvest date; then the weekly temperature was averaged by farm. 
extracts were analyzed for $\mathrm{NO}_{3}-\mathrm{N}$ and $\mathrm{NH}_{4}-\mathrm{N}$ using spectrophotometric analysis via the $\mathrm{VCl}_{3}$ and salicylate-nitroprusside methods, respectively, using a set of standard concentrations of $\mathrm{NO}_{3}-\mathrm{N}$ and $\mathrm{NH}_{4}-\mathrm{N}$ (Doane and Horwath 2003; McDaniel et al. 2013; Mulvaney et al. 1996; Sims et al. 1995; Weitzman et al. 2014). Each sample was tested for each form of nitrogen. For nitrate determination, a $20 \mu \mathrm{l}$ sample was combined with $30 \mu \mathrm{l} 2 \mathrm{M} \mathrm{KCl}$ and $250 \mu \mathrm{l} \mathrm{VCl}{ }_{3}$. Standards ranging from $0.5 \mathrm{ppm} \mathrm{NO}_{3}-\mathrm{N}$ to $20 \mathrm{ppm} \mathrm{NO}_{3}-\mathrm{N}$ were analyzed in a similar manner by combining with $2 \mathrm{M} \mathrm{KCl}$ and $\mathrm{VCl}_{3}$. For ammonium determination, $120 \mu \mathrm{l}$ of extracted sample was combined with $55 \mu \mathrm{l} 2 \mathrm{M} \mathrm{KCl}, 25 \mu \mathrm{l}$ citrate, $50 \mu \mathrm{l}$ salicylate-nitroprusside, and $25 \mu \mathrm{l}$ hypochlorite, with known standards ranging from 0.2 ppm $\mathrm{NH}_{4}-\mathrm{N}$ to $5 \mathrm{ppm} \mathrm{NH}_{4}-\mathrm{N}$ combined with reagents and analyzed similarly. A standard curve was constructed for each set of standards, at $540 \mathrm{~nm}$ and $650 \mathrm{~nm}$ wavelengths for $\mathrm{NO}_{3}$ and $\mathrm{NH}_{4}$, respectively, and sample values were calculated based on these standard curves. All standard curves had a minimum $R^{2}=0.95$. Soils were also analyzed for gravimetric water content $\left(\mathrm{g} \mathrm{H}_{2} \mathrm{O} / \mathrm{g}\right.$ soil; GWC) by weighing fresh soil, removing rocks $\geq 4 \mathrm{~mm}$ diameter, drying for $\geq 48 \mathrm{~h}$, and weighing each sample again. GWC was determined by subtracting soil dry weight from soil fresh weight, less the rocks (McDaniel et al. 2013; Mulvaney et al. 1996).

Variables associated with production conditions. Production condition variables were evaluated, primarily at the midseason visit (Table 1). Weed pressure both in and between raised beds was rated on a qualitative, ordinal 3-point scale $(1=<33 \%$ ground or mulch covered by weeds; $2=33$ to $67 \%$ ground or mulch covered by weeds; $3=>67 \%$ ground or mulch covered by weeds). Plastic mulch integrity was rated on a three-point, ordinal scale $(1=$ intact mulch, $2=$ some perforations, $3=$ very torn and/or mulch intentionally slashed). Sunscald, which is softened tissue at bulb shoulders and occurs on onion tissue exposed to prolonged periods of sunlight, was rated as a binary response for onion plots on each farm. Proximity of plastic mulch to bulbs at midseason was rated on a qualitative, ordinal 3point scale $(1=$ loose $/$ not completely touching bulb; $2=$ touching bulb completely; 3 = tight / stretched around bulb).

Variables associated with onion plant health. Foliar thrips damage was rated on a visual, 0 to $100 \%$ damage scale, modified from Nault and Shelton (2010), from 10 plants per replicate plot. Average bulb diameter at the midseason visit was visually estimated using an ordinal scale $(1=<5.1 \mathrm{~cm}, 2=5.1$ to $7.6 \mathrm{~cm}, 3=>7.6 \mathrm{~cm})$. Purple blotch, a fungal disease caused by Alternaria porri, was rated on an ordinal 3 -point scale $(0=$ less than $10 \%$ plants affected; $1=10$ to $25 \%$ plants affected; $2=>25 \%$ of plants affected).

To determine tissue nitrogen content at the midseason visit, the fifth leaf of 10 equidistantly spaced plants per plot was harvested, composited in a paper bag, and dried in a $65^{\circ} \mathrm{C}$ drying oven for $\geq 48 \mathrm{~h}$. At the harvest visit, one asymptomatic, jumbo-sized bulb from the storage rating from each of the three grower plots per field was placed in a labeled paper bag and dried for $\geq 72 \mathrm{~h}$ at $60^{\circ} \mathrm{C}$. Thoroughly dried leaf and bulb tissue samples from each replicate plot were separately ground to a fine, homogenous powder using a Cyclone Sample Mill grinder (UDY Corporation, Fort Collins, CO) and maintained in tightly capped $50 \mathrm{ml}$ (2011) or $25 \mathrm{ml}$ (2012) centrifuge tubes until analysis. Analysis was performed in the Soils Research Cluster Lab in the Department of Plant Sciences at Penn State using protocols modified from Russo (2008) and Westerveld et al. (2003). Briefly, approximately $4 \mathrm{~g}$ of each replicate sample was tared in a 502-186 foil cup (LECO Corporation, St. Joseph, MI), then folded over to completely contain the powdered sample. Samples were analyzed via dry combustion in EA1110 CHNSO Elemental Analyzer (Thermo Fisher Scientific, Milan, Italy), which produced a report containing the $\mathrm{C}$ and $\mathrm{N}$ content of each sample. Elemental contents were calculated based on the weight of the sample analyzed. Analytical standards were interspersed every 10 unknown samples to ensure gas flow was maintained in the CHNSO Elemental Analyzer.

Incidence of bacterial disease in harvested and storage onions. A $4.6 \mathrm{~m}$ section from the inner two rows of the center of each $9.1 \mathrm{~m}$ plot was harvested by hand-pulling bulbs and removing the onion foliage with pruning shears 2.5 to $3.8 \mathrm{~cm}$ above the shoulder of the bulb, grading by size, and visually evaluating onion neck and bulb tissue for bacterial disease symptoms to determine disease incidence (approximately 60 bulbs per plot). The neck of each onion was examined for any discolored scales and/or maceration, and the surface of each bulb was also examined for maceration of the outer scales. Onions were graded into four size categories based on the bulb diameter: $<6.4 \mathrm{~cm}$ diameter were graded small, 6.4 to $7.6 \mathrm{~cm}$ diameter were medium, 7.6 to $10.2 \mathrm{~cm}$ diameter were jumbo, and $>10.2 \mathrm{~cm}$ diameter were colossal (National Onion Association 2011). From each replicate plot, approximately 30 jumbo-size, visually asymptomatic bulbs were retained for postharvest storage evaluation (described below). If 30 jumbo-size, asymptomatic bulbs were not obtained, the difference was comprised of asymptomatic mediumsized bulbs.

Table 3. Multiple linear regression analysis of environmental and management variables related to bacterial rots of onion, with field as a sampling unit $(\mathrm{N}=23)^{\mathrm{a}}$. Independent variables, chosen based on Pearson's correlations $(P<$ 0.5 ) were placed in PROC PHREG (Best Subsets selection procedure), with total bacterial rot incidence as the dependent variable. Three models of two, three, and four variables were each regressed, and after logarithmic transformation of the dependent disease incidence variable, the model with the highest adjusted $R^{2}$ is shown below, $R^{2}=0.406$; adj. $R^{2}=0.312 ; P=0.017$.

\begin{tabular}{lccrc}
\hline Predictor & Coefficient & SE of coefficient & T value & $\boldsymbol{P}$ value \\
\hline Constant & 11.35 & 3.550 & 3.19 & 0.005 \\
Foliar N, midseason $^{\mathrm{b}}$ & -0.575 & 0.178 & -3.22 & 0.005 \\
Foliar C, midseason $^{\mathrm{b}}$ & -0.222 & 0.083 & -2.67 & 0.015 \\
Early-season soil nitrate $^{\mathrm{c}}$ & 0.005 & 0.002 & 2.49 & 0.022 \\
\hline
\end{tabular}

${ }^{\text {a }}$ Three observations had missing values.

${ }^{\mathrm{b}}$ The fifth leaf from 10 equidistantly spaced plants was collected at midseason, bulked by plot, dried, homogenized, and analyzed for each of total $\mathrm{N}$ and $\mathrm{C}$ via dry combustion. Three replicate plots were averaged by field prior to analysis.

${ }^{c}$ Soil from the first farm visit was analyzed for nitrate using the $\mathrm{VCl}_{3}$ protocol.

Table 2. Multiple linear regression analysis of PA-2011 dataset using each field as a sample $(\mathrm{N}=27)^{\mathrm{a}}$. Independent environmental and management variables, chosen based on Pearson's correlations $(P<0.5)$, were placed in PROC PHREG (Best Subsets selection procedure), with total bacterial rot incidence as the dependent variable. Three models of two, three, and four variables were each regressed, and the model with the highest adjusted $R^{2}$ was chosen, $R^{2}=0.618$; adj. $R^{2}=0.568 ; P<0.001$.

\begin{tabular}{|c|c|c|c|c|}
\hline Predictor & Coefficient & SE of coefficient & T value & $P$ value \\
\hline Constant & -195.00 & 74.70 & -2.62 & 0.015 \\
\hline Foliar N, midseason ${ }^{\mathrm{b}}$ & -41.57 & 7.77 & -5.35 & $<0.001$ \\
\hline Average soil T, 3 weeks preharvest ${ }^{\mathrm{c}}$ & 14.16 & 3.41 & 4.15 & $<0.001$ \\
\hline Season-long hours with soil $\mathrm{T}>30^{\circ} \mathrm{C}^{\mathrm{d}}$ & -0.08 & 0.04 & -1.89 & 0.071 \\
\hline
\end{tabular}

a A single data observation was missing for one variable.

$\mathrm{b}$ The fifth leaf from 10 equidistantly spaced plants was collected midseason, bulked by plot, dried, homogenized, and analyzed for total C and $\mathrm{N}$ via dry combustion. Three replicate plots were averaged by field prior to analysis.

${ }^{\mathrm{c}}$ Average soil temperatures at the $7.6 \mathrm{~cm}$ depth within planting bed, during the time period 14 to 21 days preharvest.

${ }^{\mathrm{d}}$ Season-long, cumulative hours with soil temperatures $>30^{\circ} \mathrm{C}$ at the $7.6 \mathrm{~cm}$ depth. 
Postharvest bulb evaluation. Approximately 30 asymptomatic, jumbo-size onions per replicate plot were cured under burlap in a greenhouse with forced air for at least $72 \mathrm{~h}$, then placed in $4^{\circ} \mathrm{C}$ storage for 75 to 120 days (depending on harvest date). In late November of each sample year, stored bulbs were evaluated for disease incidence by inspecting outer scales for maceration, then bulbs were sliced in half longitudinally. Bulbs with outer maceration, or inner scale discoloration and/or maceration, were denoted as a percentage of the 30 bulbs per replicate plot.

Confirmation of bacterial disease. Tissue from each of 657 bulbs was aseptically transferred from the margin between symptomatic and asymptomatic areas to sterile $1.8 \mathrm{ml}$ tubes. Approximately $0.5 \mathrm{~g}$ tissue was lyophilized for $4 \mathrm{~h}$ at $-40^{\circ} \mathrm{C}$ with vacuum $(<150$ mTorr), ground, and extracted for DNA using the Promega DNA extraction kit. Briefly, $600 \mu \mathrm{l}$ of Promega Nuclei Lysis Solution was combined with ground dried tissue, vortexed, and incubated for $30 \mathrm{~min}$ at $65^{\circ} \mathrm{C}$. Next, $200 \mu \mathrm{l}$ of $10 \mathrm{M} \mathrm{NH}_{4} \mathrm{CH}_{3} \mathrm{COO}$ was added, vortexed, and frozen at $-20^{\circ} \mathrm{C}$ for $10 \mathrm{~min}$. Tubes were centrifuged for $5 \mathrm{~min}$ at $13,000 \times \mathrm{g}$, then supernatants were transferred to sterile tubes with $600 \mu \mathrm{l}$ isopropanol, which were inverted several times followed by centrifugation for $5 \mathrm{~min}$ at $13,000 \times g$. Supernatants were decanted, and the pellet was washed with $600 \mu 170 \%$ ethanol and centrifuged $1 \mathrm{~min}$ at $13,000 \times \mathrm{g}$. After decanting the $70 \%$ ethanol supernatant, the pellet was dried for $1 \mathrm{~h}$, followed by resuspension of the pellet in $100 \mu \mathrm{l}$ TE buffer.

PCR protocols (Mansfield and Gugino 2010) were conducted as follows using extracted DNA. Primer sets used to identify $P$. marginalis, $P$. carotovorum, and $P$. agglomerans were $P$ marF (ACCTACGTCCACGGTGT) - PmarR (AGCAGGAAGTCGGA GAAGTA); PcarF (CGACAACTTCGGTATCGTTGA) - PcarR (GAAGCGGCTTTGATGGCT); and $\mathrm{PaggF}$ (ACGGGTGAGACC GACATTAC) - PaggR (GTAGGGTGAATCGGGGTTTT). PCR cycling conditions were: (1) initial denaturation at $96^{\circ} \mathrm{C}$ for $10 \mathrm{~min}$, followed by 34 cycles of $(2) 99^{\circ} \mathrm{C}$ for $30 \mathrm{~s}$, (3) $60^{\circ} \mathrm{C}$ or $62^{\circ} \mathrm{C}$ for $1 \mathrm{~min}$, (4) $72^{\circ} \mathrm{C}$ for $1 \mathrm{~min}$; then a final elongation at (5) $72^{\circ} \mathrm{C}$ for $5 \mathrm{~min}$ and storage at $(6) 4^{\circ} \mathrm{C}$ continuous. The annealing temperature for the $P$. agglomerans reactions was $60^{\circ} \mathrm{C} ; P$. marginalis and $P$. carotovorum reactions annealed at $62^{\circ} \mathrm{C}$. Amplification was confirmed with a $1 \%$ agarose gel with expected amplicon sizes of 651,322 , and $248 \mathrm{bp}$ for P. marginalis, $P$. carotovorum, and P. agglomerans, respectively (Mansfield and Gugino 2010).

Data analysis. Values for each variable were represented by the average of three replicate plots per field, and each field was treated as a sample for each year, with the collected and analyzed variables listed in Table 1. For disease datasets, total disease incidence was analyzed as the dependent variable, which was the sum of the incidence of bacterial disease at harvest, plus the incidence of bacterial disease after storage as a percentage of the remaining marketable bulbs. An additional analysis using pre- or concurrently sampled variables was conducted with foliar $\mathrm{N}$ at midseason as the dependent variable using PROC PHREG with the combined-year dataset.
For the individual year datasets, management variables were first placed in a Pearson's correlation matrix, then variables were input into PROC PHREG (best subsets procedure; SAS 9.2, SAS Institute, Cary, NC), with three models requested. All variables could not be placed in PROC PHREG since the number of variables exceeded the number of samples in singular-year datasets (Tables 2 and 3), and a correlation with $P<0.5$ was chosen based on this indicating at least a weak univariate correlation. PROC PHREG then output three combinations of independent variables with highest $\chi^{2}$ scores for each overall number of variables. Generally, simpler regression models are easier to maintain, may be interpreted more clearly, and prevent excessive interactive effects (Kutner et al. 2005; p. 347). Three models composed of two, three, or four variables from PROC PHREG output were then analyzed in PROC REG to evaluate model fit. The model with the highest adjusted $R^{2}$ value is reported; models with multiple nonsignificant variables $(P>0.05)$ were not chosen. All analyses were completed using SAS 9.2. In the 2012 regression analysis dataset, total bacterial disease incidence was logarithmically transformed to ensure normality in the residuals (Table 3 ). In each of the final models shown for yearly data and foliar N, one observation was removed due to Cook's D $>0.5$, which indicates this observation had a strong influence on the respective regression functions (Kutner et al. 2005; p. 403). The influential observations from the yearly data were also removed from the combined dataset prior to best subsets fitting.

Simple slopes analysis to interpret the foliar $\mathrm{C} \times$ average soil temperature 5 weeks preharvest interaction was completed using PROC

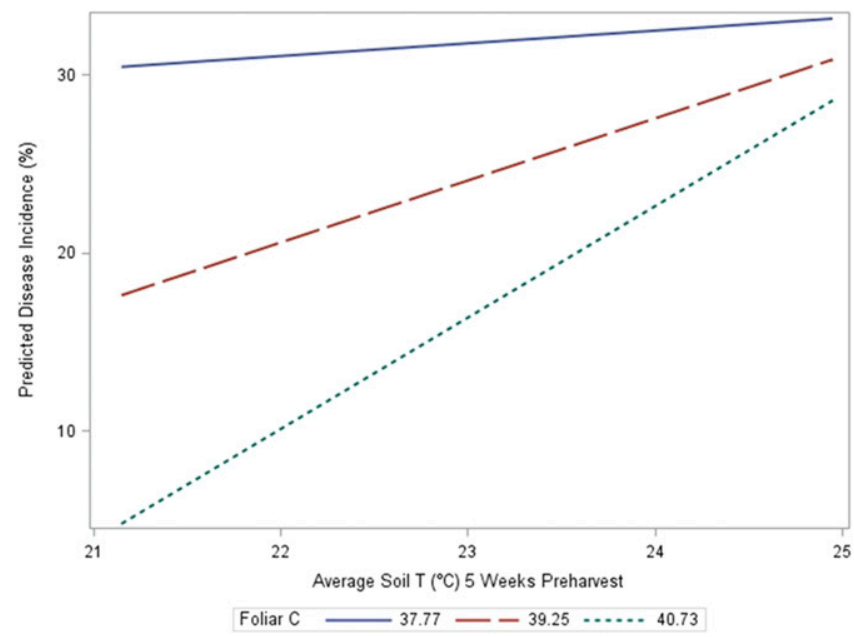

Fig. 1. Simple slopes analysis for interpretation of midseason foliar $C$ by average soil T 5 weeks preharvest interactive effects on bacterial disease incidence in onion, from 2011 and 2012 in Pennsylvania. Values input for foliar C are the mean of the observed sample set \pm the standard deviation.

Table 4. Multiple linear regression analysis of environmental and management variables related to bacterial rots of onion, using the combined 2011 and 2012 datasets and with field as a sampling unit $(\mathrm{N}=49)^{\mathrm{a}}$. Independent variables were placed in PROC PHREG (Best Subsets selection procedure), with total bacterial rot incidence as the dependent variable. Three models of two, three, and four variables were each regressed, and the model with the highest adjusted $R^{2}$ was chosen, $R^{2}=0.364 ;$ adj. $R^{2}=0.307 ; P<0.001$.

\begin{tabular}{|c|c|c|c|c|}
\hline Predictor & Coefficient & SE of coefficient & T value & $P$ value \\
\hline Constant & 2400.08 & 831.99 & 2.88 & 0.006 \\
\hline Foliar N, midseason ${ }^{\mathrm{b}}$ & -28.20 & 7.41 & -3.80 & $<0.001$ \\
\hline Foliar C, midseason ${ }^{\mathrm{b}}$ & -61.06 & 21.71 & -2.81 & 0.007 \\
\hline Average soil $\mathrm{T}, 5$ weeks preharvest ${ }^{\mathrm{c}}$ & -88.83 & 35.55 & -2.50 & 0.016 \\
\hline Foliar $\mathrm{C} *$ soil T 5 weeks preharvest interaction & 2.38 & 0.93 & 2.56 & 0.014 \\
\hline
\end{tabular}

a Five observations were not included; four were missing data for one of the variables, and the other was removed due to having a Cook's D $>0.5$ (Kutner et al 2005).

${ }^{\mathrm{b}}$ The fifth leaf from 10 equidistantly spaced plants was collected midseason, bulked by plot, dried, homogenized, and analyzed for total C and $\mathrm{N}$ via dry combustion. Three replicate plots were averaged by field prior to analysis.

${ }^{c}$ Average soil temperatures at the $7.6 \mathrm{~cm}$ depth within planting bed, during the time period 29 to 35 days preharvest. 
PLM and PROC SGPLOT (Lin 2015). This process projected predicted disease incidences based on the covariance matrix of the regression model and values entered for foliar $\mathrm{C}$ at midseason and average soil T 5 week preharvest. Values entered for foliar $\mathrm{C}$ were the mean \pm one standard deviation from the combined-year dataset. Values for average soil T 5 week preharvest were entered using 'do' statements starting at one standard deviation below the mean and increasing by 0.2 increments to one standard deviation above the mean of the combined dataset. Authors relied greatly on SAS code published by Lin (2015).

\section{Results}

In 2011 and 2012, data were collected from the variables listed in Table 1, and simple statistics are reported in Supplementary Table S1. In 2011, bacterial disease incidence at harvest from the set of 28 fields ranged from 0 to $50.2 \%$ and bacterial disease incidence from storage ranged from 2.1 to $41.6 \%$. The total disease incidence per field, therefore, ranged from 3.3 to $69.5 \%$ and was the dependent variable for the model in Table 2. Independent variables included in PROC PHREG from Pearson's correlations are highlighted in Supplementary Table $\mathrm{S} 2$, with total incidence of bacterial rot as the dependent variable. The three best subsets models returned by PROC PHREG for each dataset are reported with model selection criteria in Supplementary Table S3. Subsets of 20 and 50\% symptomatic bulbs from the harvest and postharvest storage evaluations, from 2011 and 2012, respectively, were retained for bacterial species isolation and identification. Over $90 \%$ of symptomatic bulbs $(n=592)$ tested positive via species-specific PCR (Mansfield and Gugino 2010) for at least one bacterial species of interest, and 50\% $(n=$ 329) tested positive for multiple bacterial species. The most frequently identified species in symptomatic bulbs were $P$. carotovorum (61\%), P. agglomerans (37\%), and P. marginalis (29\%). Specific details on bacterial species detections and their relationships with other variables are beyond the scope of this article.

The selected model to describe the 2011 dataset included foliar $\mathrm{N}$ from full-size, asymptomatic leaves collected at midseason $(P<$ $0.001)$, average soil temperature during 3 weeks prior to harvest (14 to 21 days prior; 3 -week soil temperature; $P<0.001$ ), and cumulative hours of soil $\mathrm{T}$ greater than $30^{\circ} \mathrm{C}(P=0.071)$. When two- and three-way interactions were included in repeated analyses of this model, none approached statistical significance $(P>0.1$; data not shown). Negative relationships were indicated between each of foliar $\mathrm{N}$ and cumulative hours with soil $\mathrm{T}>30^{\circ} \mathrm{C}$ and total bacterial disease incidence, while a positive relationship was indicated between average 3 -week preharvest soil temperature and total bacterial disease incidence (Table 2).

In 2012, bacterial disease incidence at harvest from the set of 26 fields ranged from 0 to $14.7 \%$, and bacterial disease incidence from storage ranged from 6.7 to $64.1 \%$. Total bacterial incidence for the set, therefore, ranged from 7.6 to $68.6 \%$, which was transformed logarithmically and was the dependent variable for the model. The selected model included foliar $\mathrm{N}$ and foliar $\mathrm{C}$ from full-size, asymptomatic leaves collected at midseason as well as early-season soil $\mathrm{NO}_{3}$; none of the interactions were significant (Table 3; data not shown). A positive relationship between total bacterial rot incidence and levels of soil $\mathrm{NO}_{3}$ early in the season was indicated $(P=0.022)$, along with negative relationships between each of foliar $\mathrm{N}$ and $\mathrm{C}$ and the dependent total bacterial disease variable $(P<0.02$; Table 3$)$.

In the combined-year dataset, total bacterial rot incidence ranged from 3.3 to $69.5 \%$ among 54 fields participating in either year. Since the sample size was large enough to input all variables into PROC PHREG, all independent variables were included in the model selection step. The selected model included foliar $\mathrm{N}(P<0.001)$ and foliar $\mathrm{C}(P=0.006)$ from full-size, asymptomatic leaves collected at midseason and average soil T 5 weeks preharvest $(P=0.013)$; there was a significant interaction between foliar $\mathrm{C}$ and average soil $\mathrm{T}$ at 5 weeks preharvest $(P=0.014$; Table 4$)$. Investigating the interaction further (Fig. 1) through simple slopes analysis (Aiken and West 1991; Lin 2015), it was found that bacterial disease was projected to be high at low levels of foliar C, regardless of soil T 5 weeks preharvest. Disease incidence projections indicated a positive effect of soil $\mathrm{T} 5$ weeks preharvest when foliar $\mathrm{C}$ was at or above average (Fig. 1). In the combined year dataset, the $\mathrm{C} / \mathrm{N}$ ratio of foliage collected at midseason was itself a predictor of total bacterial disease incidence (Fig. 2); however, inclusion of the individual foliar tissue test variables explained more total variation in the dataset.

Since foliar $\mathrm{N}$ was a significant factor in the three previous analyses, PROC PHREG was used to identify independent variables measured prior to or at foliar tissue sampling that were related to foliar $\mathrm{N}$. The chosen model indicated foliar $\mathrm{C}(P<0.001)$ and average bulb diameter $(P=0.101)$ at midseason were each negatively related to foliar N, while silt content of soils was positively related to foliar $\mathrm{N}(P=0.001$; Table 5).

\section{Discussion}

Intensive replicated sampling of PA onion fields in 2011 and 2012 indicated one novel trend among all datasets and another in several datasets that support results from previous research on bacterial

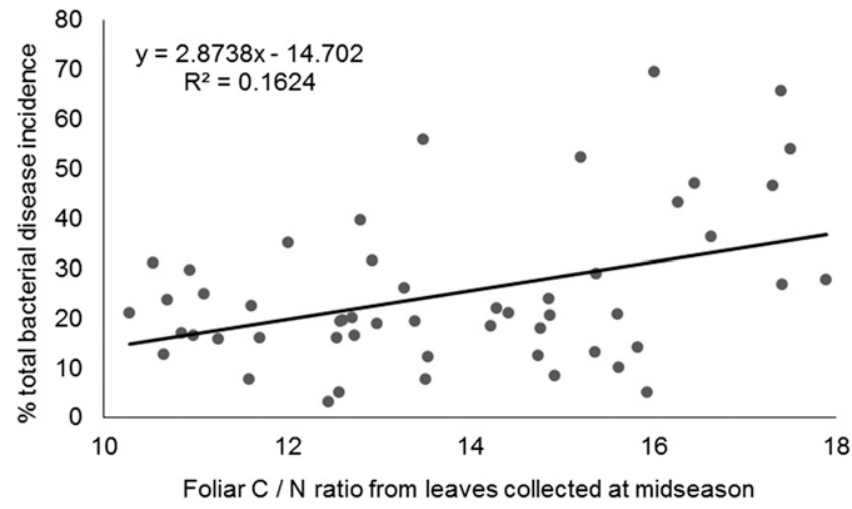

Fig. 2. Foliar $\mathrm{C} / \mathrm{N}$ from leaves collected at midseason regressed with total bacterial disease incidence from Pennsylvania in 2011 and 2012. A single observation was removed due to foliar thrips damage at midseason more than 2 standard deviations higher than the mean. $R^{2}=0.162$; adj. $R^{2}=0.146 ; P=0.003$.

Table 5. Multiple linear regression analysis of environmental and management variables related to foliar nitrogen at midseason, using the combined 2011 and 2012 datasets and with field as a sampling unit $(\mathrm{N}=49)^{\mathrm{a}}$. Independent variables were placed in PROC PHREG (Best Subsets selection procedure), foliar N at midseason as the dependent variable. Three models of 1,2 , and 3 variables were each regressed, and the model with the highest adjusted $R^{2}$ was chosen, $R^{2}=$ $0.561 ;$ adj. $R^{2}=0.531 ; P<0.001$.

\begin{tabular}{|c|c|c|c|c|}
\hline Predictor & Coefficient & SE of coefficient & T value & $P$ value \\
\hline Constant & 8.02 & 0.980 & 8.15 & $<0.001$ \\
\hline Foliar C, midseason ${ }^{\mathrm{b}}$ & -0.16 & 0.023 & -6.67 & $<0.001$ \\
\hline Silt content of soil ${ }^{\mathrm{c}}$ & 0.02 & 0.010 & 3.51 & 0.001 \\
\hline Avg. size of bulbs at midseason ${ }^{\mathrm{d}}$ & -0.08 & 0.050 & -1.68 & 0.101 \\
\hline
\end{tabular}

a Five observations were not included; four were missing data for one of the variables, and the other was removed due to Cook's D $>0.5$ (Kutner et al. 2005).

$\mathrm{b}$ The fifth leaf from 10 equidistantly spaced plants was collected at midseason, bulked by plot, dried, homogenized, and analyzed for total $\mathrm{C}$ via dry combustion.

Three replicate plots were averaged by field prior to analysis.

${ }^{c}$ The midpoint of the range of silt values, as reported in the NRCS soil survey database, was reported for each field.

${ }^{\mathrm{d}}$ Visual estimate of the size of onion bulbs at the midseason visit (in $2.5 \mathrm{~cm}$ increments, from under 5.1 to above 7.6 ). 
diseases of onion in other production regions. Plant nutritional variables, such as foliar $\mathrm{N}$, foliar $\mathrm{C}$, and/or soil nitrate levels, were significant factors related to total bacterial disease incidence (Tables 2 to 4; Fig. 2). In addition, average soil temperatures near the physiological onset of bulbing (Tables 2 and 4; Fig. 1) were positively related to total disease incidence.

Relationships between foliar $\mathrm{N}$ and bacterial rots (Tables 2 to 4 ) are in direct contrast to a-priori hypotheses, wherein excessive $\mathrm{N}$ fertility was thought to result in higher levels of bacterial disease, which has been suggested in other onion systems (Diaz-Perez et al. 2003; Gitaitis et al. 2008; Mohan 2008). Instead, the negative relationship between midseason foliar $\mathrm{N}$ and bacterial disease incidence may indicate that $\mathrm{N}$-stressed Candy onion plants may be more susceptible to bacterial infection, proliferation, and/or movement into the onion bulb, as has been demonstrated in the $P$. ananatis-onion pathosystem (Carr et al. 2013; Stumpf et al. 2017). Virulence genes induced by Erwinia amylovora and Pseudomonas syringae during infection have been shown to be upregulated under N-limiting conditions in vitro (Snoeijers et al. 2000), which may be similar for the gramnegative bacterial pathogens in this system. Since multiple bacterial species have been detected from symptomatic onions, connections between virulence genes and $\mathrm{N}$-limiting conditions would require further experimentation using representative strains of each species. Other studies report that tissue $\mathrm{N}$ levels may differ by onion cultivar (Westerveld et al. 2003), and a range of susceptibility to common bacterial pathogens of onion exists (Stumpf et al. 2017), so further research is necessary to determine potential interactive effects between cultivar and $\mathrm{N}$ fertility in relation to disease incidence.

Two multiple regression datasets suggest foliar $\mathrm{C}$ at midseason is related to total bacterial disease incidence (Tables 2 and 4). Pearson's correlations, however, do not suggest univariate relationships between midseason foliar $\mathrm{C}$ and bacterial disease incidence in onion, even though foliar $\mathrm{N}$ and $\mathrm{C}$ are negatively correlated (Table 5). However, no interaction between these variables was suggested in any of the selected multiple regression models (Tables 2 to 4). Further, when foliar $\mathrm{C}$ and foliar $\mathrm{N}$ were expressed as a ratio and regressed with total bacterial disease incidence, foliar $\mathrm{C} / \mathrm{N}$ ratio at midseason was positively related to disease (Fig. 2). $\mathrm{C} / \mathrm{N}$ ratios are commonly used to describe soils and organic matter, and $\mathrm{C} / \mathrm{N}$ ratios of cover crops and composts have been implied to have positive (Grünwald et al. 2000) or negative (Hoitink et al. 1997) relationships with soilborne fungal and oomycete pathogens. Relationships between high $\mathrm{N}$ content in plant tissue and bacterial disease have been reviewed thoroughly (Dordas 2008; Hoffland et al. 2000; Snoeijers et al. 2000), yet we struggled to identify relationships between $\mathrm{C} / \mathrm{N}$ ratios in living plant tissue and bacterial disease in the literature. This may suggest that specific assays with inoculated, differentially fertilized onion plants are necessary to fully elucidate the effects of high tissue $\mathrm{C} / \mathrm{N}$ ratios on bacterial disease incidence and severity.

Another plant nitrogen-related variable positively related to bacterial disease incidence was early-season soil $\mathrm{NO}_{3}$, from the 2012 dataset (Table 3). These results are similar to those reported in other pathosystems, where levels of soil $\mathrm{NO}_{3}$ were positively correlated with bacterial disease incidence (Huber and Watson 1974; Rotenberg et al. 2005) and may coincide with elevated disease incidence observed in low-lying areas of fields (E. Pfeufer and B. Gugino, unpublished), since $\mathrm{NO}_{3}$ is water-soluble and mobile in soils. In addition, silt content of soils was positively related to levels of foliar $\mathrm{N}$ (Table 5), which together indicate site selection, and the type of $\mathrm{N}$ fertilizer applied may be of practical interest to growers producing Candy onions. Nitrogen cycling is dependent on a number of soil characteristics, including temperature, moisture, oxygen, $\mathrm{pH}$, organic matter, and microbial diversity (Daroub and Snyder 2007), and more silt in soils may help ensure optimal levels of these characteristics.

Positive relationships between soil temperatures 3 or 5 weeks preharvest and the total incidence of bacterial rots were observed in the 2011 and combined-year datasets (Tables 3 and 4). Positive relationships between air temperature and bacterial disease have already been established in various onion pathosystems (Gitaitis et al. 2008; Mohan 2008; Schwartz et al. 2003), and soil temperatures have been suggested to be associated with center rot of onion, caused by $P$. ananatis and $P$. agglomerans (Diaz-Perez et al. 2003; Gitaitis et al. 2003). Pathogen species identification in the present study, however, differs from the previous in that the most commonly identified pathogens were $P$. carotovorum subsp. carotovorum, $P$. marginalis pv. marginalis, and P. agglomerans (E. Pfeufer and B. Gugino, unpublished). In addition, 3 and 5 weeks preharvest in PA roughly correspond with the physiological onsets of bulb initiation and bulb swelling, which relates well to results reported by Schwartz et al. (2003) and Stumpf et al. (2017). High temperatures at bulbing were associated with initial onset of Xanthomonas leaf streak in onion (Schwartz et al. 2003), which occurs rarely in PA (E. Pfeufer and B. Gugino, unpublished), and inoculations completed at bulb initiation and swelling resulted in center rot disease incidence (Stumpf et al. 2017) similar to the upper range of incidence reported here. In plastic mulch systems, soil temperature may be moderated by using mulches of different colors or materials, which may be purchased at a price premium (i.e., black biodegradable or silver; Gugino et al. 2011; C. A. Hoepting, unpublished). In light of a suggested soil temperature-bacterial disease relationship, some profitconscious onion growers in PA chose to cut their standard black plastic mulch at the shoulders of established raised beds at the onset of bulbing to increase air flow, which they anecdotally reported as effective in reducing bacterial disease (Multiple Lancaster Onion Coop growers, to E. Pfeufer). Replicated trials, however, are necessary before recommending this practice.

The identification of management and environmental factors associated with increased bacterial disease incidence will facilitate further research trials to develop more targeted research-based management recommendations for onion growers in the Mid-Atlantic region. Relationships between midseason foliar $\mathrm{N}$ and $\mathrm{C}$, soil $\mathrm{NO}_{3}$, and total incidence of bacterial rots of onion (Tables 2 to 5; Fig. 2) warrant further investigation into the type and timing of $\mathrm{N}$ fertility applications and their effects on foliar $\mathrm{N}$ and $\mathrm{C}$ levels in relation to disease incidence. Finally, the positive relationship between soil temperatures and bacterial rot incidence (Tables 3 and 4) reinforces previously reported data from other locations (Diaz-Perez et al. 2003; Gitaitis et al. 2004, 2008; Mohan 2008; Schwartz et al. 2003) and supports the use of alternate plastic mulches or cutting mulch during onion bulbing.

\section{Acknowledgments}

Soil nitrate, ammonium, and PMN were processed in Dr. Jason Kaye's lab in the Department of Ecosystem Resource Management at Penn State, with the assistance of Dr. Kaye, Sara Eckert, and Kaye lab members. Foliar and bulb tissue $\mathrm{N}$ and $\mathrm{C}$ content were processed in the Soils Research Cluster Lab at Penn State with the assistance of Dr. Ephraim Govere. Technical assistance was provided by Dr. Michele Mansfield, Elizabeth Buck, Dr. Steve Beer and members of the Beer lab, Tim Grove, Ilse Huerta, Evan Stover, Jill Pollok Robert Bressler, Andrew Hower, Khanh Nguyen, Lizzie King'ang'i, Rosemary Schwegel, Marie Ebner, Anna Testen, Laura Ramos, Laura del Sol Bautista, and Andy Kelly. The authors thank Dr. Larry Madden for a helpful conversation about statistical analyses and all the grower cooperators across Pennsylvania.

\section{Literature Cited}

Aiken, L. S., and West, S. G. 1991. Multiple Regression: Testing and Interpreting Interactions. SAGE Publications, Thousand Oaks, CA.

Carr, E. A., Zaid, A. M., Bonasera, J. M., Lorbeer, J. W., and Beer, S. V. 2013. Infection of onion leaves by Pantoea ananatis leads to bulb infection. Plant Dis. 97:1524-1528.

Conover, R. A., and Gerhold, N. R. 1981. Mixtures of copper and maneb or mancozeb for control of bacterial spot of tomato and their compatibility for control of fungus diseases. Proc. Fla. State Hortic. Soc. 94:154-156.

Daroub, S. H., and Snyder, D. H. 2007. The chemistry of plant nutrients in soil. Pages 1-7 in: Mineral Nutrition and Plant Disease. L. E. Datnoff, W. H. Elmer, and D. M. Huber, eds. APS Press, St. Paul, MN.

Diaz-Perez, J. C., Purvis, A. C., and Paulk, J. T. 2003. Bolting, yield, and bulb decay of sweet onion as affected by nitrogen fertilization. J. Am. Soc. Hortic. Sci. 128:144-149.

Doane, T. A., and Horwath, W. R. 2003. Spectrophotometric determination of nitrate with a single reagent. Anal. Lett. 36:2713-2722.

Dordas, C. 2008. Role of nutrients in controlling plant diseases in sustainable agriculture. A review. Agron. Sustain. Dev. 28:33-46. 
Dutta, B., Anderson, F., Smith, S., and Gitaitis, R. 2017. Epiphytic survival of Pantoea ananatis on Richardia scabra L. in Georgia. Plant Dis. 101:613-618.

Dutta, B., Barman, A. K., Srinivasan, R., Avci, U., Ullman, D. E., Langston, D. B., and Gitaitis, R. D. 2014. Transmission of Pantoea ananatis and P. agglomerans, causal agents of center rot of onion (Allium cepa), by onion thrips (Thrips tabaci) through feces. Phytopathology 104:812-819.

Dutta, B., Gitaitis, R., Barman, A., Avci, U., Marasigan, K., and Srinivasan, R. 2016. Interactions between Frankliniella fusca and Pantoea ananatis in the center rot epidemic of onion (Allium cepa). Phytopathology 106:956-962.

Edens, D. G., Gitaitis, R. D., Sanders, F. H., and Nischwitz, C. 2006. First report of Pantoea agglomerans causing a leaf blight and bulb rot of onions in Georgia. Plant Dis. 90:1551.

Gent, D. H., and Schwartz, H. F. 2005. Management of Xanthomonas leaf blight of onion with a plant activator, biological control agents, and copper bactericides. Plant Dis. 89:631-639.

Gent, D. H., and Schwartz, H. F. 2008. Bacterial stalk and leaf necrosis. Pages 66-67 in: Compendium of Onion and Garlic Diseases and Pests, 2nd Ed. APS Press, St. Paul, MN.

Gitaitis, R., Walcott, R., Culpepper, S., Sanders, H., Zolobowska, L., and Langston, D. 2003. Recovery of Pantoea ananatis, causal agent of center rot of onion, from weeds and crops in Georgia, USA. Crop Prot. 21:983-989.

Gitaitis, R. D., Gent, D. H., and Schwartz, H. S. 2008. Leaf streak and bulb rot. Page 59 in: Compendium of Onion and Garlic Diseases and Pests, 2nd Ed. APS Press, St. Paul, MN.

Gitaitis, R. D., Walcott, R. R., Sanders, H. F., Zolobowska, L., and Diaz-Perez, J. C. 2004. Effects of mulch and irrigation system on sweet onion: II. The epidemiology of center rot. J. Am. Soc. Hortic. Sci. 129:225-230.

Grünwald, N. J., Hu, S., and van Bruggen, A. H. C. 2000. Short-term cover crop decomposition in organic and conventional soils: Characterization of soil C, N, microbial, and plant pathogen dynamics. Eur. J. Plant Pathol. 106:37-50.

Gugino, B. K., Hoepting, C. A., Stoltzfus, J., Mansfield, M. A., Klotzbach, K., and Reid, J. E. 2011. Management of onion bacterial diseases using alternative mulches and plant spacing. Phytopathology 101:S65.

Hoffland, E., Jegger, M. J., and van Beusichem, M. L. 2000. Effect of nitrogen supply rate on disease resistance in tomato depends on the pathogen. Plant Soil 218:239-247.

Hoitink, H. A. J., Stone, A. G., and Han, D. Y. 1997. Suppression of plant diseases by composts. HortScience 32:184-187.

Huber, D. M., and Watson, R. D. 1974. Nitrogen form and plant disease. Annu. Rev. Phytopathol. 12:139-165.

Imhoff, J. F. 2005. Enterobacteriales. Pages 587-850 in: Bergey's Manual of Systematic Bacteriology. Vol. 2: The Proteobacteria, Part B: The Gammaproteobacteria. G. Garrity, D. J. Brenner, N. R. Krieg, and J. R. Staley, eds. Springer, New York.

Kawamoto, S. O., and Lorbeer, J. W. 1967. Soft rot bacteria associated with onion decay. Phytopathology 57:341-342.

Kutner, M. H., Nachtsheim, C. J., Neter, J., and Li, W. 2005. Building the regression model I: Model selection and validation; and Building the regression model II: Diagnostics. Pages 343-404 in: Applied Linear Statistical Models. McGraw-Hill, Boston.

Lin, A. 2015. SAS Seminar: Analyzing and visualizing interactions. UCLA: Statistical Consulting Group. Accessed 5 July 2015: https://stats.idre.ucla. edu/sas/seminars/analyzing-and-visualizing-interactions/

Mansfield, M. A., and Gugino, B. K. 2010. Multiplex PCR for simultaneous detection of eight major onion bacterial pathogens. Phytopathology 100:S77.

McDaniel, M. D., Kaye, J. P., and Kaye, M. W. 2013. Increased temperature and precipitation had limited effects on soil extracellular enzyme activities in a postharvest forest. Soil Biol. Biochem. 56:90-98.
Mohan, S. K. 2008. Other bacterial soft rots. Page 62 in: Compendium of Onion and Garlic Diseases and Pests, 2nd Ed. APS Press, St. Paul, MN.

Mulvaney, R., Sparks, D., Page, A., Helmke, P., Loeppert, R., Soltanpour, P., Tabatabai, M., Johnston, C., and Sumner, M. 1996. Nitrogen-inorganic forms. Pages 1123-1184 in: Methods of Soil Analysis. Part 3-Chemical Methods. American Society of Agronomy-Soil Science Society of America, Madison, WI.

National Onion Association. 2011. Sizes and packaging options. Accessed 22 January 2016 from https://www.onions-usa.org/retail/sizes-and-packagingoptions.

Nault, B. A., and Shelton, A. M. 2010. Impact of insecticide efficacy on developing action thresholds for pest management: A case study of onion thrips (Thysanoptera: Thripidae) on onion. J. Econ. Entomol. 103:1315-1326.

Nischwitz, C., Gitaitis, R., Sanders, H., Langston, D., Mullinix, B., Torrance, R. Boyhan, G., and Zolobowska, L. 2007. Use of fatty acid methyl ester profiles to compare copper-tolerant and copper-sensitive strains of Pantoea ananatis. Phytopathology 97:1298-1304.

Obradovic, A., Jones, J. B., Balogh, B., and Momol, M. T. 2008. Integrated management of tomato bacterial spot. Pages 211-223 in: Integrated Management of Diseases Caused by Fungi, Phytoplasma, and Bacteria. A. Ciancio and K. G. Mukerji, eds. Springer Science and Business Media, Berlin.

Rotenberg, D., Cooperband, L., and Stone, A. 2005. Dynamic relationship between soil properties and foliar disease as affected by annual additions of organic amendment to a sandy-soil vegetable production system. Soil Biol. Biochem. 37:1343-1357.

Russo, V. M. 2008. Plant density and nitrogen fertilizer rate on yield and nutrient content of onion developed from greenhouse-grown transplants. HortScience 43:1759-1764

Sanchez, E., Elkner, T. E., Lamont, W. J., Demchak, K., Orzolek, M. D., Gugino, B. K., Halbrendt, J. M., Fleischer, S. J., LaBorde, L., Hoffman, K., and San Julian, G. J. 2014. Commercial Vegetable Production Recommendations Pennsylvania 2014. Penn State Cooperative Extension, Pennsylvania Agricultural Experiment Station, and The Pennsylvania State University, University Park, PA.

Schwartz, H. F., Otto, K. L., and Gent, D. H. 2003. Relation of temperature and rainfall to development of Xanthomonas and Pantoea leaf blights of onion in Colorado. Plant Dis. 87:11-14.

Sims, G. K., Ellsworth, T. R., and Mulvaney, R. L. 1995. Microscale determination of inorganic nitrogen in water and soil extracts. Commun. Soil Sci. Plant Anal. 26:303-316.

Snoeijers, S. S., Perez-Garcia, A., Joosten, M. H. A. J., and De Wit, P. J. G. M. 2000. The effect of nitrogen on disease development and gene expression in bacterial and fungal plant pathogens. Eur. J. Plant Pathol. 106:493-506.

Stumpf, S., Gitaitis, R., Coolong, T., Riner, C., and Dutta, B. 2017. Interaction of onion cultivar and growth stages on incidence of Pantoea ananatis bulb infection. Plant Dis. 101:1616-1620.

Tho, K. E., Wiriyajitsomboon, P., and Hausbeck, M. K. 2015. First report of Pantoea agglomerans causing onion leaf blight and bulb rot in Michigan. Plant Dis. 99:1034.

Weitzman, J. N., Forshay, K. J., Kaye, J. P., Mayer, P. M., Koval, J. C., and Walter, R. C. 2014. Potential nitrogen and carbon processing in a landscape rich in milldam legacy sediments. Biogeochemistry 120:337-357.

Westerveld, S. M., McKeown, A. W., Scott-Dupree, C. D., and McDonald, M. R. 2003. How well do critical nitrogen concentrations work for cabbage, carrot, and onion crops? HortScience 38:1122-1128.

Wright, P. J. 1993. Effects of nitrogen fertilizer, plant maturity at lifting, and water during field-curing on the incidence of bacterial soft rot of onions in store. N.Z. J. Crop Hortic. Sci. 21:377-381. 